\title{
CHARACTERIZATION OF LITTER MORTALITY IN STRAIGHTBRED NEW ZEALAND WHITE RABBITS
}

\author{
Elmaghraby, M.M.A.* and Elkholya, S.Z.* \\ *Animal Breeding and Production, Fac. Vet. Med., Alex. Univ., Edfina \\ ** Animal and Poultry Behavior and Management, Fac. Vet. Med., \\ Alex. Univ., Bostan Branch
}

\begin{abstract}
Eight hundred sixty six kits of 104 New Zealand White litters were studied for the rate of stillbirth, within litter mortality $(M)$ between birth and day 21 of age (M0-21) where kits rely solely on milk, day 22 to weaning (M22-28) and postweaning to marketing (M29-70). Overall least squares means were 6.96\% (stillbirth), $10.62 \%$ (M0-21), 0.55\% (M22-28) and 3.08\% (M29-70). In 30.77\% of litters, all kits survived to marketing. Dead kits at birth and those died within the first week of age had significantly $(P<0.01$ and $P<0.05$, respectively) lower body weight (bwt) than their surviving littermates. M0-21 was higher (14.97 vs 6.27\%, P<0.01) in litters of low mean kit birth weight $(\leq 60 v s>60 \mathrm{~g})$. Kit survival pre- (M0-21) and postweaning (M29-70) was better when their does gained $>250 \mathrm{~g}$ bwt during the first three weeks post-kindling compared to dams losing bwt or gaining < $250 \mathrm{~g}$. The rate of stillbirth increased $(P=0.06)$ with longer gestation periods. M0-21 was higher (14.39 vs 6.86\%, $P<0.05)$ in large litters $(\geq 9$ alive kits $v s<9$ kits). Summer and spring born litters experienced higher $(P<0.05)$ M0-21 (14.98 and 14.27\%) than autumn (7.42\%) and winter $(5.81 \%)$ born ones. Parity affected only stillbirth $(P<0.05)$ with litters of the $1^{\text {st }}, 2^{\text {nd }}$ and $\geq 3^{\text {rd }}$ orders lost $5.83,4.98$ and $10.07 \%$ of
\end{abstract}


their kits at birth, respectively. Repeatability estimates were generally low (0.00 to 0.07) except for a moderate value of 0.31 for M0-21. It could be concluded that stillbirth and MO-21 are the major components of kit losses. Small kit size, dam bwt loss or low bwt gain during the first three weeks postnatal, large litters, summer and spring kindlings, and $3^{\text {rd }}$ or higher kindling orders reduced kit survival, particularly at birth and during the first three weeks of age.

Keywords: Rabbits, mortality, kit weight, doe body weight, litter size, season, parity, gestation length

\section{INTRODUCTION}

The productivity of rabbits depends principally on the number of young reaching the market and their growth rate. Chiefly because of its high prolificacy (large litter size), a rabbit doe can produce up to $80 \mathrm{~kg}$ of meat per year, which is equivalent to 2900 to $3000 \%$ of its body weight per year $(\boldsymbol{F A O}, 2001)$. Therefore, maintaining high economic efficiency in commercial rabbit production necessitates high kit survival.

Stillbirth is common and its rate is high in rabbits (Garreau et al., 2008; Guillén et al., 2008), and the early postnatal days are critical to survival of kits (Belhadi, 2004; Rödel et al., 2008b). Within large rabbit litters, there is an intensive competition among littermates for dam's milk and thermally favorable positions in the litter huddle, and weak kits of low birth weight are more likely to die because of starvation (Drummond et al., 2000; Bautista et al., 2005; Bautista et al., 2008). In addition to the size of the nursing litter, kit body mass, litter homogeneity, and doe body mass and its physiological condition could affect its caring ability and subsequently kit survival (Seitz et al., 1998; 
Elmaghraby et al., 2004; Zerrouki et al., 2005; Bonanno et al., 2008; Garreau et al., 2008; Rödel et al., 2008b). Also, seasonal differences in kit losses have been recorded (Bhatt et al., 2002; Marai et al., 2002; Belhadi, 2004).

The objective of the present study was to describe the pattern of within litter rabbit mortality at birth, preweaning and postweaning in a population of purebred New Zealand White rabbits in relation to some potential influential factors.

Abbreviations: M0-21, mortality between birth and day 21 of age; M2228, mortality between days 22 and 28 of age; M29-70; mortality postweaning to marketing; bwt, body weight.

\section{MATERIALS AND METHODS}

Rabbits of the present study were purebreds of the New Zealand White breed. They were raised in El-Tamboli rabbit farm, a large producer of meat rabbits. The farm is located in El-Obour city, CairoIsmailia road. Females were mated for the first time at $4-6$ months of age. After kindling, remating occurred after 10 days, and pregnancy was diagnosed via abdominal palpation $12-14$ days post-mating. After three weeks of nursing, kits were allowed a complete pelleted ration composed of (in $\mathrm{kg}$ ) hay 320, wheat bran 200, soybean meal 120, corn 120, barely 200 , molasses 20 , sodium chloride 5 , limestone 8 , sodium bicarbonate 5 and mineral mixture 2. Breeding bucks and non-lactating does were given about $150 \mathrm{~g}$ of the same ration daily, whereas weaned kits and lactating does were fed ad libitum. After 28 days, kits were weaned, sexed, ear-tagged, and weighed individually. 


\section{Traits and statistical analyses:}

866 kits of 104 litters of purebred New Zealand White rabbits were investigated for within litter mortality (M). Mortality was recorded at birth (stillborn), within the first three weeks (M0-21), $22^{\text {nd }}$ day to weaning (M22-28), and postweaning to marketing (M29-70). The least squares statistical model for M0-21, M22-28 and M29-70 included the fixed effects of mean kit birth weight of the litter, litter size born alive, kindling season, kindling order, and doe body weight difference between birth and day 21 of kindling.

$$
Y_{i j k l m}=\mu+K B W_{i}+D_{j}+L_{S B}+S_{l}+K_{m}+e_{i j k l} \text {, where }
$$

$\mathbf{Y}_{\mathbf{i j k l m}} \quad$ observed value of a given dependent variable

$\boldsymbol{\mu} \quad$ overall mean

$\mathbf{K B W}_{\mathbf{i}} \quad$ fixed effect of $\mathrm{i}^{\text {th }}$ mean kit birth weight of the litter (Low, litters with mean kit birth weight $\leq 60 \mathrm{~g}$; High, litters with mean kit birth weight $\geq 61$ )

$\mathbf{D}_{\mathbf{j}} \quad$ fixed effect of $\mathbf{j}^{\text {th }}$ doe body weight difference between birth and day 21 post-kindling (Losing weight, gaining $<250 \mathrm{~g}$, and gaining $\geq 250 \mathrm{~g}$ )

$\mathbf{L S B}_{\mathbf{k}} \quad$ fixed effect of $\mathrm{k}^{\text {th }}$ litter size born alive (Small, $<9$; large, $\geq 9$ kits)

S fixed effect of $1^{\text {th }}$ kindling season (autumn, September to November; winter, December to February; spring, March to May; summer, June to August)

$\mathbf{K}_{\mathbf{m}} \quad$ fixed effect of $\mathrm{m}^{\text {th }}$ kindling order $\left(1^{\text {st }}, 2^{\text {nd }}\right.$ and $\left.\geq 3^{\text {rd }}\right)$

e 
For stillbirth, the same previous model was used except for the following modifications: total litter size at birth (alive and dead) was used and classified as small ( $<10$ kits) and large ( $\geq 10 \mathrm{kits})$, and doe body weight at kindling (Light does $<4.5 \mathrm{~kg}$, and Heavy does $\geq 4.5 \mathrm{~kg}$ ) in addition to gestation length in days as a covariate. In both models most two-way interactions were non-significant, and therefore removed from the final analyses. Separate simple linear regression of stillbirth on gestation length was performed.

Within the same litter, body weight of dead and survivor kits at birth and within the first week were compared using the t-test. All analyses were performed using the Statistical Analysis System (SAS, 2002). Means were separated using the least squares means of the same program. Results from arcsine transformed and non-transformed data did not differ, therefore the normal scale was used.

Repeatability was estimated as $\left(\sigma^{2} \mathrm{~S}+\sigma_{\mathrm{D}}^{2}\right) /\left(\sigma^{2} \mathrm{~S}+\sigma_{\mathrm{D}}^{2}+\sigma^{2} \mathrm{E}\right)$ where $\sigma^{2} \mathrm{~S}, \sigma_{\mathrm{D}}^{2}$, and $\sigma^{2} \mathrm{E}$ are sire, doe within sire and remainder variance components, respectively. Approximate standard errors were computed using the LSMLMW software of Harvey (1990).

\section{RESULTS AND DISCUSSION}

Table (1) provides statistical description of the rabbit litters under investigation. Overall, kit mortality occurred in 72 (69.23\%) of litters up to marketing. Rödel et al. (2008b) recorded deaths in $42.7 \%$ of litters during the nest period of European rabbits living in a field enclosure. Birth through the first three weeks post-kindling, where the kits relay solely on their mother's milk, is a critical period to litter survival $(6.96 \%$ stillbirth; 10.62\% M0-21). Farghaly (1996) reported a total preweaning mortality of $21 \%$ largely due to stillbirth followed by M0-20 and M2130. Higher rates (13.9 and $15.9 \%$ ) of stillbirth were previously recorded by Leone-Singer and Hoop(2003)and Guillén et al.(2008), respectively. 
Elmaghraby, M.M.A. \& Elkholya, S.Z.

Table (1): Descriptive statistics of New Zealand White litters under investigation.

\begin{tabular}{|c|c|c|c|c|}
\hline Variable & Minimum & Maximum & Arithmetic Mean & STD \\
\hline \multicolumn{5}{|l|}{ Litter size (number) } \\
\hline Total born & 1 & 13 & 8.33 & 2.50 \\
\hline Born alive & 1 & 13 & 7.84 & 2.70 \\
\hline Born dead & 0 & 6 & 0.49 & 0.99 \\
\hline Day 21 post-kindling & 1 & 11 & 6.81 & 2.31 \\
\hline Day 28 (weaning) & 1 & 11 & 6.76 & 2.30 \\
\hline Day 70 (marketing) & 0 & 11 & 6.53 & 2.38 \\
\hline \multicolumn{5}{|l|}{ Within litter mortality (\%) } \\
\hline Stillbirth & 0 & 66.67 & $6.68(6.96)^{*}$ & 12.66 \\
\hline \multicolumn{5}{|l|}{ Preweaning } \\
\hline Birth to day 21 & 0 & 69.23 & $11.20(10.62)^{*}$ & 16.67 \\
\hline Days 22 to 28 & 0 & 25.00 & $0.58(0.55)^{*}$ & 3.17 \\
\hline Postweaning (Days 29-70) & 0 & 80.00 & $3.14(3.08)^{*}$ & 9.32 \\
\hline Litters with all kits survivin & \multicolumn{4}{|c|}{ Number $=32(30.77 \%$ of 104 litters $)$} \\
\hline
\end{tabular}

Number of litters $=104$.

STD = Standard deviation .

* Values between parentheses are overall least squares means.

\section{Kit body weight:}

Effect of mean kit birth weight on within litter mortality is illustrated in Figure (1). Litters with high mean kit birth weight (> $60 \mathrm{~g}$ ) had significantly higher $(\mathrm{P}<0.01)$ preweaning survival $(\mathrm{M} 0-21=6.27 \%)$ compared to litters with low mean kit birth weight (14.97\%). Moreover, bwt of dead and surviving kits of the same litter differed significantly at birth (51.7 vs $65.0 \mathrm{~g}, \mathrm{P}<0.01$; Figure 2) and within the first week postkindling (77.8 vs $98.5 \mathrm{~g}, \mathrm{P}<0.05$; Figure 2), which implies that death within a litter was confined mostly to smaller, and eventually weaker, kits. 
The importance of bwt during the early postnatal period for kit survival has been previously reported. Seitz et al. (1998) found kit losses to decrease with the increase of birth weight $77 \%$ for kit birth weight < $30 \mathrm{~g}$ to only $9.9 \%$ for birth weight $>71 \mathrm{~g}$ ). Also, Bautista et al. (2008) reported that dead kits averaged $10 \mathrm{~g}$ less at birth, weighed $29.2 \%$ less within the first 5 days postnatal, and had no milk in their stomachs compared to the survivors. Heavier kits compete more effectively for mother's milk and favorable thermal positions in the litter huddle, grow faster and are better able to maintain body equilibrium than lighter kits (Drummond et al., 2000; Bautista et al., 2008; Muciño et al., 2008; Rödel et al., 2008a,b). Therefore, they are more likely to survive.

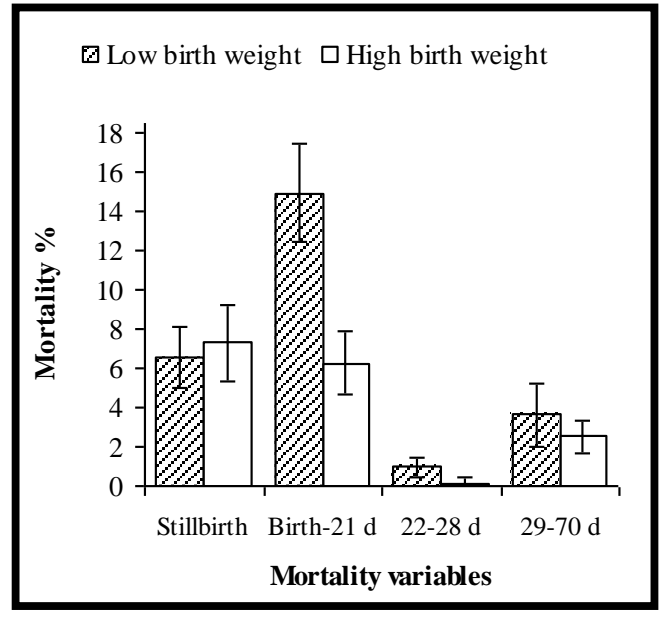

Fig.(1): Effect of mean kit birth weight on within litter mortality

Low (litters with mean kit birth weight $\leq 60$ $\mathrm{g}, \mathrm{n}=54$ litters), High (litters with mean kit birth weight $\geq 61, \mathrm{n}=50$ litters).

Values are least squares means and their standard errors.

Differences in within litter mortality from Birth-21 d, were significant $(\mathrm{P}<0.01)$, other variables did not differ $(\mathrm{P}>0.05)$.

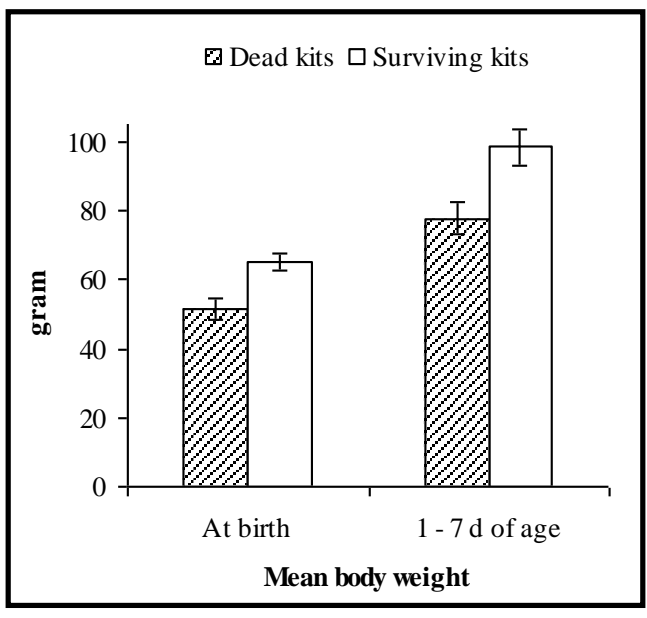

Fig.(2): Body weight of dead and surviving kits of the same litter at birth and within the first week post-kindling

Values are least squares means and their standard errors.

Differences were significant $(\mathrm{P}<0.01$ at birth, $\mathrm{n}=32 ; \mathrm{P}<0.05$ during the first week post-kindling, $\mathrm{n}=31$.) 


\section{Doe body weight:}

Doe bwt at kindling had no effect on stillbirth (Table 2). Gaining more than $250 \mathrm{~g}$ in doe bwt during the first three weeks post-kindling was beneficial to the survival of their litters pre- and postweaning $(\mathrm{P}<$ 0.05 , Table 2). Their M0-21 (6.12\%) and M29-70 (0.74\%) were 7.81 and $1.7 \%$ less than the respective mortalities of litters from does gaining less than $250 \mathrm{~g}$ bwt, as well, 5.69 and $5.32 \%$ less than the corresponding mortalities of litters produced by does losing bwt post-kindling. Bonanno et al. (2008) found that poor body condition of does was linked to higher mortality of nursed kits during 1-11 days postpartum (10.3, 2.2 and $4.5 \%$ for body condition scores 0,1 and 2 , respectively; $\mathrm{P}<0.001$ ).

Table (2): Effect of doe body weight on stillbirth (\%) and change in doe body weight between birth and day 21 post-kindling on within litter mortality variables $(\%)$.

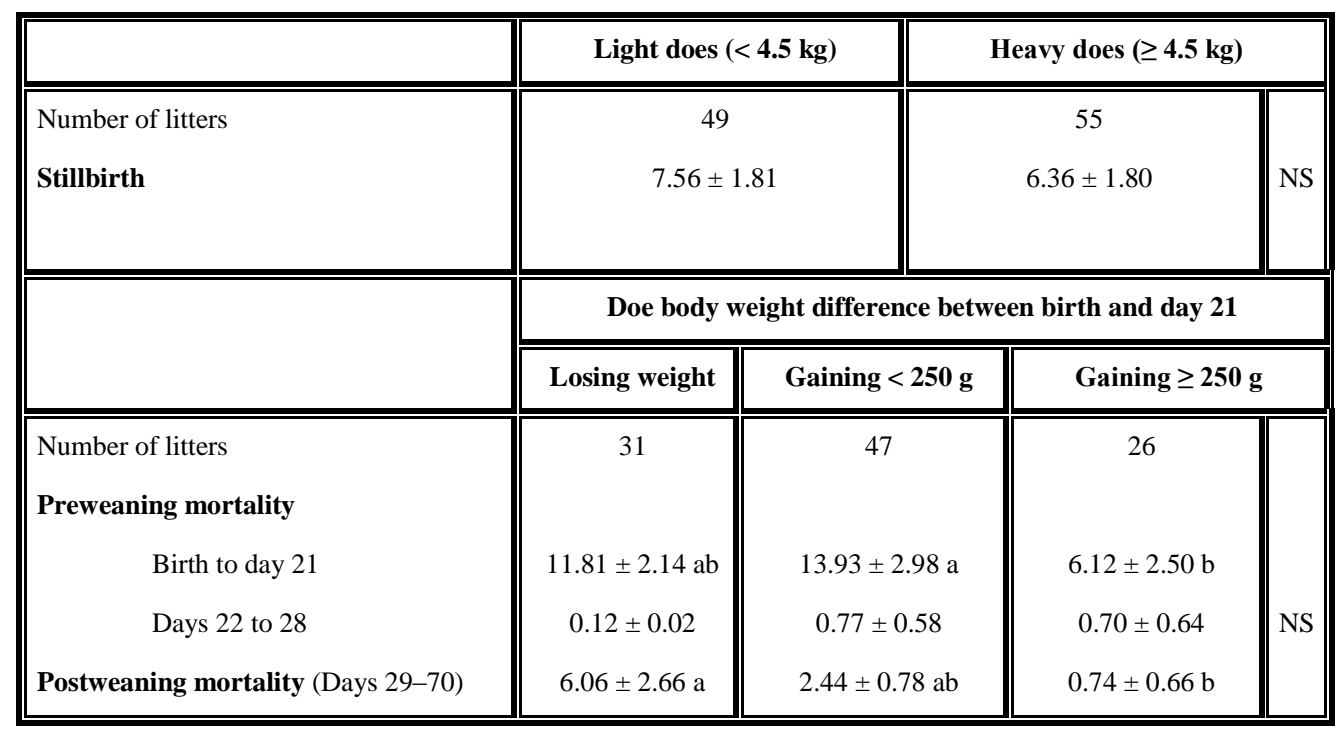

Values are least squares means \pm standard errors.

Different letters in a row indicate significant difference $(\mathrm{P}<0.05)$; NS $=$ not significant $(\mathrm{P}>0.05)$.

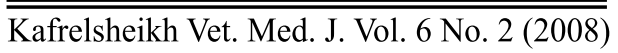




\section{Effect of litter size at birth and gestation length:}

Figure (3) demonstrates that large litters at birth ( $\geq 9$ alive kits) had significantly $(\mathrm{P}<0.05)$ higher mortality than small litters $(<9$ kits $)$ between birth and day 21 (14.39 vs 6.86\%). Stillbirth (8.54 vs 5.38\%), M22-28 (0.91 vs $0.15 \%$ ) and M29-70 (4.01 vs 2.15) were numerically, but not statistically $(\mathrm{P}>0.05)$, higher in small litters.

The effect of gestation length (GL) on stillbirth approached significance in the analysis of covariance $(\mathrm{P}=0.09)$ and simple linear regression $(\mathrm{P}=0.06)$ indicating that longer gestation periods are associated with higher stillbirth. [Equation: Stillbirth $(\%)=-66.159+$ 2.294 (GL in days)]. However, the small coefficient of determination $\left(\mathrm{R}^{2}\right.$ $=0.03$ ) makes the predictability of the equation questionable.

In agreement with the current findings, Depres et al. (1997) and Kpodekon et al. (2006) recorded an increase in preweaning mortality with the increase in litter size. Elmaghraby et al. (2004) reported a positive correlation $(\mathrm{r}=0.64, \mathrm{P}<0.01)$ between litter size and preweaning mortality in large litters (10-14 kits) compared to a correlation of only 0.20 ( $\mathrm{P}>0.05$ ) in small litters (1-9 kits). For large litters, 9-13 kits in the current study, limited number of teats (8-10) in rabbit females (Szendrö et al., 1992), and once-a-day nursing (GonzalezMarsical, 2007), there would be an exhaustive competition among littermates for milk and well-insulated (thermally advantageous) positions in the litter cluster (Bautista et al., 2005; Bautista et al., 2008). According to previous findings, milk available to individual kits decreases with the increase of litter size (Ayyat and Marai, 1998; Zerrouki et al., 2005). Weak competitors might, therefore, suffer starvation and are more likely to die (Farougou et al., 2006). Practically, reducing the size of the nursing litter through crossfostering to a maximum of nine kits per litter could reduce preweaning mortality from 20.24 to $8 \%$ (Elmaghraby and Mahrous, 2007). 
Fig. (3): Effect of litter size at birth on within litter mortality.

For stillbirth, total litter size at birth (alive and dead) was used and classified as small $(<10$ kits, $\mathrm{n}=51$ litters $)$ and large $(\geq 10$ kits, $\mathrm{n}=53$ litters). For other mortality traits, litter size born alive was used and classified as small $(<9, \mathrm{n}=53$ litters $)$ and large ( $\geq 9$ kits, $\mathrm{n}=51)$.

Values are least squares means and their standard errors.

Differences in within litter mortality from Birth-21 d mortality were significant $(\mathrm{P}<$

๒Small litters $\square$ Large litters

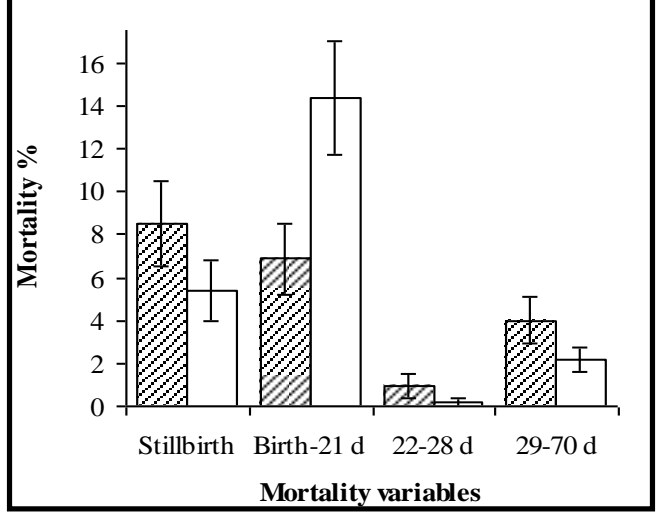
$0.05)$, other variables did not differ $(\mathrm{P}>$ $0.05)$.

\section{Effect of kindling season:}

Kindling season influenced significantly M0-21 (Table 3). Litters born during summer and spring months suffered approximately twice M0-21 recorded for autumn born ones, and twofold and half of winter born litters $(\mathrm{P}<0.05)$. Stillbirth rate was numerically $(\mathrm{P}>0.05)$ the least during winter, which agrees with the finding of Belhadi (2004) on local Algerian rabbits. Previous studies also demonstrated seasonal variation in mortality parameters (Farghaly, 1996; Bhatt et al., 2002). Marai et al. (2002, 2004) mentioned that long daylight and summer heat stress of Egypt adversely affect performance of rabbits including kit survival preand post-weaning. High ambient temperature (above $26 \mathrm{C}$ ) reduces feed intake of lactating does by 25 to $50 \%$ leading to energy deficit and deterioration of doe body condition and productivity (a review by Fortun-Lamothe, 2006). 
Table (3): Effect of kindling season on within litter mortality variables (\%).

\begin{tabular}{|c|c|c|c|c|c|}
\hline & \multicolumn{5}{|c|}{ Kindling season } \\
\hline & Autumn & Winter & Spring & Summer & \\
\hline Number of litters & 32 & 30 & 22 & 20 & \\
\hline Stillbirth & $9.78 \pm 2.87$ & $4.78 \pm 2.01$ & $6.06 \pm 2.50$ & $7.20 \pm 2.37$ & NS \\
\hline \multicolumn{5}{|l|}{ Preweaning mortality } & \\
\hline Birth to day 21 & $7.42 \pm 2.03 \mathrm{~b}$ & $5.81 \pm 1.73 \mathrm{~b}$ & $14.27 \pm 3.32 \mathrm{a}$ & $14.98 \pm 3.19 \mathrm{a}$ & \\
\hline Days 22 to 28 & $0.45 \pm 0.60$ & $0.40 \pm 0.71$ & $0.82 \pm 0.53$ & $0.54 \pm 0.65$ & NS \\
\hline Postweaning mortality (Days 29-70) & $4.47 \pm 2.54$ & $4.13 \pm 1.32$ & $1.16 \pm 0.75$ & $2.56 \pm 1.03$ & NS \\
\hline
\end{tabular}

Values are least squares means \pm standard errors.

Different letters in a row indicate significant difference $(\mathrm{P}<0.05)$; NS $=$ not significant $(\mathrm{P}>0.05)$.

\section{Kindling order:}

Litters of the third and higher kindlings showed the highest stillbirth $(10.07 \%, \mathrm{P}<0.05)$ compared to those of the first $(5.83 \%)$ and second $(4.98 \%)$ parities (Table 4$)$. Other pre- and postweaning mortality variables did not vary $(\mathrm{P}>0.05)$ with the parity order. Guillén et al. (2008) reported a similar trend for stillbirth, but they found significantly increasing M0-21 with the advance of parity. Does in the current study were remated 10 days after kindling. Except during the first pregnancy, most does were lactating and pregnant concurrently, and might therefore suffer energy deficit. Fetal growth and viability are affected by the energy status of the doe (Fortun-Lamothe et al., 1999; FortunLamothe, 2006). Oguike and Okocha (2008) could reduce stillbirth from 3.67 to 0.00 and $0.33 \%$ by increasing the remating interval from 3 to 4 and 5 weeks, respectively. 
Elmaghraby, M.M.A. \& Elkholya, S.Z.

Table (4): Effect of kindling order on within litter mortality variables (\%)

\begin{tabular}{|c|c|c|c|c|}
\hline & \multicolumn{4}{|c|}{ Kindling order } \\
\hline & $1^{\text {st }}$ & $2^{\text {nd }}$ & \multicolumn{2}{|c|}{$3^{\text {rd }}$ or more } \\
\hline Number of litters & 30 & 25 & 49 & \\
\hline Stillbirth & $5.83 \pm 1.65 b$ & $3.98 \pm 1.62 \mathrm{~b}$ & $10.07 \pm 2.90 \mathrm{a}$ & \\
\hline \multicolumn{5}{|l|}{ Preweaning mortality } \\
\hline Birth to day 21 & $8.81 \pm 2.69$ & $12.32 \pm 4.19$ & $10.72 \pm 2.21$ & NS \\
\hline Days 22 to 28 & $0.53 \pm 0.62$ & $0.91 \pm 0.73$ & $0.21 \pm 0.55$ & NS \\
\hline Postweaning mortality (Days 29-70) & $5.38 \pm 2.77$ & $2.12 \pm 1.05$ & $1.74 \pm 0.78$ & NS \\
\hline
\end{tabular}

Values are least squares means \pm standard errors.

Different letters in a row indicate significant difference $(\mathrm{P}<0.05)$; NS $=$ not significant $(\mathrm{P}>0.05)$.

\section{Repeatability estimates:}

Estimates of repeatability of mortality variables are presented in Table (5). Stillbirth and postweaning mortality were lowly repeatable. But, M0-21 had moderate repeatability indicating that culling does with high first litter preweaning mortality would be effective in raising litter survival. Farghaly (1996) reported low repeatability estimates for stillbirth and preweaning mortality.

Table (5): Repeatability estimates of within litter mortality variables.

\begin{tabular}{|l|c|}
\hline \hline Stillbirth & Repeatability \\
Preweaning & $0.04 \pm 0.07$ \\
Birth to day 21 & \\
Days 22 to 28 & $0.31 \pm 0.19$ \\
Postweaning (Days 29-70) & $0.00 *$ \\
\hline \hline
\end{tabular}

* Negative sire and dam variance components were set to zero

$\overline{\text { Kafrelsheikh Vet. Med. J. Vol. } 6 \text { No. } 2 \text { (2008) }}$ 


\section{Conclusion and Applications:}

It could be concluded that (1) Stillbirth and kit mortality during the first three weeks postnatal account for most (17.58 of 21.21\%) of kit losses until marketing. (2) Small kit size, dam bwt loss or low weight gain during the first three weeks postnatal, large litters, summer and spring kindlings, and $3^{\text {rd }}$ or higher kindling orders adversely affect kit survival, particularly at birth and during the first three weeks of age. Management adjustment e.g. crossfostering to reduce litter size and increase litter homogeneity, improving post-kindling doe energy balance via increasing remating interval to avoid concurrent lactation and pregnancy particularly during higher parities, reducing heat stress, and culling does with high first litter preweaning mortality would improve overall kit survival.

\section{REFERENCES}

- Ayyat, M.S. and Marai, I.F.M. (1998): Evaluation of application of the intensive rabbit production system under the subtropical conditions of Egypt. World Rabbit Sci., 6(1): 213-217.

- Bautista, A.; García-Torres, E.; Martinez-Gómez, M. and Hudson, R. (2008): Do newborn domestic rabbits Oryctolagus cuniculus compete for thermally advantageous positions in the litter huddle? Behav. Ecol. Sociobiol., 62: 331-339.

- Bautista, A.; Mendoza-Degante, M.; Coureaud, G.; MartinezGómez, M. and Hudson, R. (2005): Scramble competition in newborn domestic rabbits for an unusually restricted milk supply. Animal Behav., 70: 1011-1021. 
- Belhadi, S. (2004): Characterization of local rabbit performances in Algeria: Environmental variation of litter size and weights. Proc. $8^{\text {th }}$ World Rabbit Congress, 7-10 October, 2004, P. 218-223.

- Bhatt, R.S.;Sharma, S.R.; Singh,U.;Kumar,D.and Bhasin, V.(2002): Effect of different seasons on the performance of grey giant rabbits under sub-temperate Himalayan conditions. Asian-Aust. J. Anim. Sci., 15(6): 812-820.

- Bonanno A.; Mazza F.; Di Grigoli A. and Alicata M.L. (2008): Body condition score and related productive responses in rabbit does. $9^{\text {th }}$ World Rabbit Congress, Verona - Italy, 297-301.

- Depres, E.; Marie-Nely, H.; Demerson, D. and tSaleil, G. (1997): Doe rabbit performances in Martinique. Arch. Latinoam. Prod. Anim., 5 (Suppl. 1): 338-340.

- Drummond, H.; Vázquez, E.; Sánchez-Colón, S.; Martinez-Gómez, M. and Hudson, R. (2000): Competition for milk in the domestic rabbit: Survivors benefit from littermate deaths. Ethology, 106(6): $511-526$.

- Elmaghraby, M.M.A. and Mahrous, O.E. (2007): Influence of some preweaning factors and crossfostering on market traits of New Zealand White rabbits. Benha Vet. Med. J., 181; 269-285.

- Elmaghraby, M.M.A.; Helal, M.A. and El-Sheikh, A.I. (2004): Maximum number of kits a rabbit doe should nurse for optimum litter performance up to weaning. $4^{\text {th }}$ Scientific Conference for Veterinary Medical Researches, Fac. Vet. Med., Alex. Univ., 2 - 4 October 2004, P. 658-672. 
- FAO. (2001): Press Release 01/57. FAO recognizes the increasingly important role of rabbit breeding global rabbit production exceeds 1 million tones. http://www.fao.org/ WAICENT/ OIS /PRESS _NE/ PRESSENG/ 2001 /pren0157.htm. 2001 PRESS RELEASES of Food and Agriculture Organization of the United Nations.

- Farghaly, H.M. (1996): Genetic and maternal variance components of stillbirths and pre-weaning mortality in purebred rabbits. Indian J. Anim. Sci., 66(9): 907-913.

- Farougou, S.; Kpodekon, M.; Koutinhouin, B.; Brahi, O.D.H.; Djago, Y.; Lebas, F. and Coudert, P. (2006): Impact of immediate postnatal sucking on mortality and growth of sucklings in field condition. World Rabbit Sci., 14(3): 167-173.

- Fortun-Lamothe, L. (2006): Energy balance and reproductive performance in rabbit does. Anim. Reprod. Sci., 93: 1-15.

- Fortun-Lamothe, L.; Prunier, A.; Bolet, G. and Lebas, F. (1999): Physiological mechanisms involved in the effects of concurrent pregnancy and lactation on fetal growth and survival in the rabbit. Livest. Prod. Sci., 60: 229-241.

- Garreau, H.A.; Bolet, G.A.; Larzul, C.B.; Robert-Granie, C.A.; Saleil, G.A.; San Cristobal, M.C. and Bondin, L.A. (2008): Results of four generations of canalizing selection for rabbit birth weight. Livestock Sci., In Press doi: 10.1016/j.livsci.2008.02.009.

- Gonzalez-Marsical, G. (2007): Mother rabbits and their offspring: Timing is everything. Develop. Psychobiol., 49(1): 71-76. 
- Guillén O.; Villalobos O. and García J.(2008): Effect of remating interval, weaning age and parity on rabbit doe performance under heat stress. $9^{\text {th }}$ World Rabbit Congress, Verona - Italy, 1551-1554.

- Harvey, W.R. (1990): User's guide for LSMLMW. Mixed model least squares and maximum likelihood computer program. Ohio State University, Columbus, USA.

- Kpodekon, M.; Youssao, A.K.I.; Koutinhouin, B.; Djago, Y.; Houezo, M. and Coudert, P. (2006): Influence of non-genetic factors on the mortality of young rabbits in the south of Benin. Annales de Medecine Veterinaire, 150(3): 197-201.

- Leone-Singer, A.and Hoop, R. (2003): Suckling mortality in fattening rabbits in Switzerland. Schweiz. Arch. Tierheilkd., 145(7): 329-35.

- Marai, I.F.M.; Habeeb, A.A.M. and Gad, A.E. (2002): Rabbits' productive, reproductive and physiological performance traits as affected by heat stress: A review. Livestock Prod. Sci., 78(2): 71-90.

- Marai, I.F.M.; Habeeb, A.A.M. and Gad, A.E. (2004): Reproductive traits of female rabbits as affected by heat stress and lighting regime under subtropical conditions of Egypt. Anim. Sci., 78(1): 119-127.

- Muciño, E.; Bautista, A.; Jiménez, I.; Martínez-Gómez, M. and Hudson, R. (2008): Differential development of body equilibrium among littermates in the newborn rabbit. Develop. Psychobiol., In Press doi. 10.1002/dev.20339. 
- Oguike, M.A. and Okocha, N.L.(2008): Reproductive performance of rabbits re-mated at different intervals post-partum. Afr. J. Agric. Res., 3(6): 412-415.

- Rödel, H.G.; Bautista, A.; García-Torres, B.; Martinez-Gómez, M. and Hudson, R. (2008a): Why do heavy littermates grow better than lighter ones? A study in wild and domestic European rabbits. Physiol. Behavior, 95(3): 441-448.

- Rödel,H.G.;Starkloff,A.;Seltmann,M.W.; Prager, G. and von Holst, D. $(2008 b)$ : Causes and predictors of nest mortality in a European rabbit population. Mammalian Biol, In Press doi: 10.10 16/j. mambio. 2008.04.003.

- SAS, (2002): Statistical Analysis System, Version 9.00. User's Guide. SAS Institute Inc., Cary, NC, USA.

- Seitz, K.; Hoy, S. and Lange, K. (1998): Influence of birth weight on mortality and life weight development in rabbits. Archiv. fur Tierzucht, 41(4): 397-405.

- Szendrö, Z.; Mohamed, M.M.A.; Biró-Németh, E. and Radnai, I. (1992): Heritability of teat number of rabbits. J. Appl. Rabbit. Res., 15: $174-180$.

- Zerrouki,N.;Lebas, F.;Berchiche,M. and Bolet,G.(2005): Evaluation of milk production of a local Algerian rabbit population raised in the Tizi-Ouzou area (Kabylia). World Rabbit Sci., 13(1): 39-47. 


\section{توصيف النفوق فى خلفة أرانب النيوزيلاندى الأبيض النقية "شريف زكريا الخوليا"

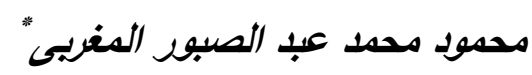

$$
\text { " التربية و الإنتاج الحيوانى - كلية الطب البيطرى - إدفينا - جامعة الإسكندرية }
$$

"* سلوكيات و رعاية الحيوان و الدوجن - كلية الطب البيطرى - البستان - جامعة الإسكندرية

تم منابعة 866 من صغار أرانب النيوزيلاندى الأبيض النقية المولودة فى عدد 104 خلفة لدراسة معدلات النفوق داخل الخلفة عند الميلاد (المولود نافق)؛ بين الميلاد و عمر 21 يوم حيث تعتمد الصغار على لبن الأم كمصدر وحيد للتغذية؛ من عمر 22 إلى 28 يوم (الفطام) و بعد الفطام حتى التسويق (29 إلى 70 يوم). المتوسط العام لمعدل النفوق كان 6.96\% (المولود نافق)؛ 10.62\% (بين الميلاد و 21 يوم)؛ 0.55\% (من 22 إلى 28 يوم) و 3.08\% (من 29 إلى 70 يوم). لم يحدث أى نفوق فى 32 خلفة (30.77\%) من الميلاد حتى النسويق.

الأرانب النافقة عن الميلاد و تللك التى نفقت فى الأسبوع الأول كان وزنها أقل معنوياً (إحتمال أقل من 0.01 و, 0.05 على التوالى) عن قرينتها الأحياء داخل نفس الخلفة. معدل النفوق بين الميلاد و عمر 21 يوم كان أعلى (14.97\% مقابل 6.27\%؛ إحتمال أقل من 0.01) فى الخلفة ذات وزن ميلاد قليل (منوسط وزن ميلاد الأرنب 60 جرام أو أقل مقارنة بوزن أكبر من 60 جرام).

حيوية الصغار قبل الفطام (من الميلاد و 21 يوم) و بعده (29 إلى 70 يوم) كانت أفضل للخلفة التى ترعاها أمهات تكتسب أكثر من 250 جرام وزن فى الثلاثة أسابيع الأولى بعد الولادة مقارنة بالأمهات التى تفقد وزن أو التى تكتسب أقل من 250 جرام خلد نفس الفترة. معدل المولود نافق إزداد 
النفوق بين الميلاد و 21 يوم من العمر كان أعلى معنوياً (14.39\% مقابل 6.86\%؛ إحتمال أقل من 0.05) فى الخلفة كبيرة العدد (9 أو أكثر من المواليد الأحياء مقارنة بأقل من 9). الخلفة المولودة فى فصول الصيف أو الربيع صاحبها معدلات نفوق أعلى (إحتمال أقل من 0.05) بين الميلاد و عمر 21 يوم (14.98\% و 14.27\% على التوالى) مقارنة بخلفة فصل الخريف (7.42\%) و الثناء .$(\% 5.81)$

ترتيب الولادة أثر معنوياً (إحتمال أقل من 0.05) فقط على معدل المولود نافق و كانت معدلاته 5.83\% فى الولادة الأولى و 4.98\% فى الثانية و 10.07\% فى الثالثة أو أكثر. كان المعامل النكرارى للنفوق ضعيفاً بثكل عام (صفر إلى 0.07) فيما عدا القيمة المتوسطة 0.31 للنفوق بين

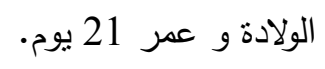

تبين من الدراسة أن المولود نافق و النفوق بين الميلاد و عمر 21 يوم تمتل المراحل الحرجة لنفوق الأرانب حتى عمر النسويق. أيضاً زادت معدلات النفوق (خاصة المولود نافق و بين الميلاد و عمر 21 يوم) فى الظروف الأتية: صغر حجم الأرنب المولود؛ الخلفة المصاحبة لأمهات تفقد وزن أو تكتبب وزن قليل فى الثلاثة اسابيع الأولى بعد الولادة؛ الخلفة ذات العدد الكبير؛ ولادات الصيف و الربيع و الولادة الثالثة أو أكثر. 